\title{
Synthesis of Bi-Heterocyclic Sulfonamides as Tyrosinase Inhibitors: Lineweaver-Burk Plot Evaluation and Computational Ascriptions
}

\author{
Muhammad Athar Abbasi, ${ }^{1,}{ }^{*}$ Zia-ur-Rehman, ${ }^{1}$ Aziz-ur-Rehman, ${ }^{1}$ \\ Sabahat Zahra Siddiqui, ${ }^{1}$ Majid Nazir, ${ }^{1}$ Mubashir Hassan, ${ }^{2}$ Hussain Raza, ${ }^{3}$ \\ Syed Adnan Ali Shah ${ }^{4}$ and Sung-Yum Seo ${ }^{3, *}$ \\ ${ }^{1}$ Department of Chemistry, Government College University, Lahore-54000, Pakistan \\ ${ }^{2}$ Institute of Molecular Biology and Biotechnology, The University of Lahore, Pakistan \\ ${ }^{3}$ College of Natural Sciences, Department of Biological Sciences, Kongju National University, Gongju, 32588, South Korea \\ ${ }^{4}$ Faculty of Pharmacy and Atta-ur-Rahman Institute for Natural Products Discovery (AuRIns), Level 9, FF3, Universiti \\ Teknologi MARA, Puncak Alam Campus, 42300 Bandar Puncak Alam, Selangor Darul Ehsan, Malaysia \\ *Corresponding author: E-mail: abbasi@gcu.edu.pk Tel: (+92)-42-111000010 Ext. 266 \\ dnalove@kongju.ac.kr Tel: (+82)-416-8508503
}

Received: 05-27-2019

\begin{abstract}
The designed bi-heterocyclic sulfonamides were synthesized through a two-step protocol and their structures were ascertained by spectral techniques including IR, ${ }^{1} \mathrm{H}$ NMR and ${ }^{13} \mathrm{C}$ NMR along with $\mathrm{CHN}$ analysis. The in vitro inhibitory effects of these sulfonamides were evaluated against tyrosinase and kinetics mechanism was analyzed by LineweaverBurk plots. The binding modes of these molecules were ascribed through molecular docking studies. These synthesized bi-heterocyclic molecules were identified as potent inhibitors relative to the standard (kojic acid) and compound $\mathbf{5}$ inhibited the tyrosinase non-competitively by forming an enzyme-inhibitor complex. The inhibition constant $K_{i}(0.09 \mu \mathrm{M})$ for compound 5 was calculated from Dixon plots. Computational results also displayed that all compounds possessed good binding profile against tyrosinase and interacted with core residues of target protein.
\end{abstract}

Keywords: Bi-heterocycles; 1-Phenylpiperazine; Sulfonamides; Tyrosinase; Chemical kinetics; Computational study

\section{Introduction}

Sulfonamides find their wide acceptance as the sulfa drugs across the world and these organic compounds have deep impacts on the biological systems owing to their numerous pharmacological activities. They are widely used to cure the bacterial infections. They find their usage as anti-cancer, anti-microbial, antiviral, anti-inflammatory and anti-tumor agents along with carbonic anhydrase inhibitors. ${ }^{1}$ The carbonic anhydrase bustles of sulfonamides possess an appreciated treatment for Alzheimer's disease. ${ }^{2}$ They are also used as anti-convulsant, anti-fungal and enzyme inhibitors. ${ }^{3,4}$

The sulfonamides bearing piperazine moiety have enhanced their role as antipsychotic compounds to cure paranoid schizophrenia, mental depression, nausea and as anticonvulsants against electroshock (MES) induced seizures. ${ }^{5,6}$ Certain other piperazine derivatives have also antimicrobial and antimalarial potentials. ${ }^{7,8}$ Piperdine derivatives have been reported to have anticancer activity. ${ }^{9}$ Some sulfonamide based piperidine derivatives have an efficient role as acetylcholinesterase inhibitors. Several other substituted piperidine based derivatives have the potential of inhibition of ureases and $\alpha$-glucosidases. ${ }^{10-13}$

Tyrosinase (polyphenol oxidase, PPO, E.C.1.14.18.1) which is a copper-containing metalloenzyme, catalyzes two major reactions in the biosynthesis pathway of melanin pigment: the hydroxylation and oxidation of monophenols to $o$-quinones (monophenolase activity) and the oxidation of $o$-diphenols to $o$-quinones (diphenolase acti- 
vity). ${ }^{14}$ Melanin is an important pigment which is found in the eyes, hair and skin of animals and especially it protects human skin against radiation. ${ }^{15,16}$ However, excessive production and hyperpigmentation of melanin is the cause of dermatological disorders such as melasma, ephelides, chloasma, freckles, melanoderma and senile lentigines and can induce inflammation such as eczema, irritant and allergic eczema, contact dermatitis, which can result in critical and emotionally distressing trouble. ${ }^{17}$

Besides the fact that enzymes and their activities are extremely necessary for life, the selective inhibition of critical enzymes is also considerably important for chemotherapeutic intervention in some diseases. Unregulated high enzyme activity results in the formation of reaction products at abnormal levels which can cause specific pathologies. Nowadays, the strategy of selective enzyme inhibition gets attention in modern pharmacy and enzymes have become interesting targets in drug therapies. ${ }^{18}$ For this reason, many organic molecules have been synthesized as specific enzyme inhibitors and continue to be synthesized. Modeling methods to ascribe the three-dimensional conformations and interactions of organic molecules with the active sites of enzymes help researchers to design new drug molecules. ${ }^{19}$

Therefore, the objective of the present study was to synthesize some new bi-heterocyclic sulfonamides, to explore their inhibitory potentials against tyrosinase enzyme and ascribe their binding interactions through molecular docking studies.

\section{Results and Discussion}

The aim of the present research work was to synthesize new biologically active compounds with low toxicity. Indeed, the current need is to introduce pharmacologically active drugs to help in pharmacy against the increasing enzyme inhibition.

\section{1. Chemistry}

In our present research work, four bi-heterocyclic sulfonamides were synthesized in two steps and their synthesis is shown in Scheme 1. In the first step, 4-(bromomethyl)benzenesulfonyl chloride (1) was reacted with various heterocyclic amines, including piperidine (2), morpholine (6), 4-methylpiperidine (9) and 3,5-dimethylpiperidine (12) to obtain respective sulfonamide containing electrophiles, 3, 7, 10 and $\mathbf{1 3}$, respectively. In the second step, these newly synthesized electrophiles were coupled with nucleophilic 1-phenylpiperazine (4) to acquire the desired bi-heterocyclic sulfonamides $5, \mathbf{8}, 11$ and $\mathbf{1 4}$. The structures of these derivatives were affirmed by spectral techniques like IR, ${ }^{1} \mathrm{H}$ NMR and ${ }^{13} \mathrm{C}$ NMR, in addition to the $\mathrm{CHN}$ analysis data. The spectral data are given in the experimental section. The successful synthe- sis of targeted bi-heterocyclic sulfonamides was achieved in good yields through a two-step protocol and the structures of these molecules were confirmed through spectral data of IR, ${ }^{1} \mathrm{H}$ NMR and ${ }^{13} \mathrm{C}$ NMR, along with $\mathrm{CHN}$ analysis. For the benefit of the reader, the structural characterization of one compound, $\mathbf{5}$, is discussed hereby. Its molecular formula, $\mathrm{C}_{22} \mathrm{H}_{29} \mathrm{~N}_{3} \mathrm{O}_{2} \mathrm{~S}$, was established by $\mathrm{CHN}$ analysis and by counting the number of protons in its ${ }^{1} \mathrm{H}$ NMR spectrum. Similarly, the counting of number of carbon resonances in its ${ }^{13} \mathrm{C}$ NMR spectrum also supported this assignment. The salient functional groups in the molecule were identified through absorption bands at $v 2986\left(\mathrm{C}-\mathrm{H}\right.$, str. of aromatic ring), $2905\left(-\mathrm{CH}_{2}\right.$ stretching), 1680 (aromatic $\mathrm{C}=\mathrm{C}$ stretching), $1382(\mathrm{~S}=\mathrm{O}), 1115$ $(\mathrm{C}-\mathrm{N}-\mathrm{C}) \mathrm{cm}^{-1}$. Two ortho-coupled doublets in its ${ }^{1} \mathrm{H}$ NMR spectrum at $\delta 7.70$ (br. d, $J=7.6 \mathrm{~Hz}, 2 \mathrm{H}, \mathrm{H}-3^{\prime}$ and $\mathrm{H}-5^{\prime}$ ), and 7.60 (br. d, $J=7.6 \mathrm{~Hz}, 2 \mathrm{H}, \mathrm{H}-2^{\prime}$ and $\mathrm{H}-6^{\prime}$ ) are typical for a 4-substituted benzenesulfonyl moiety, while a phenyl ring attached with the piperazine unit was rationalized by three signals in the aromatic region at $\delta$ 7.20 (br. t, $J=7.2 \mathrm{~Hz}, 2 \mathrm{H}, \mathrm{H}-3$ "' and H-5"'), 6.92 (br. d, $J$ $=7.7 \mathrm{~Hz}, 2 \mathrm{H}, \mathrm{H}-2$ "' and H-6"') and 6.77 (br. t, $J=6.9 \mathrm{~Hz}$, $1 \mathrm{H}, \mathrm{H}-4$ "'). The pseudo-symmetrical 1,4-piperazine unit was corroborated by overall two signals in aliphatic region at $\delta 3.14$ (br. s) and 2.87 (br. s) $(8 \mathrm{H}, \mathrm{CH}-2$ ", $\mathrm{CH}-3$ ", $\mathrm{CH}-5$ " and $\mathrm{CH}-6$ "), while a peculiar singlet at $\delta 3.63$ (s, $\left.2 \mathrm{H}, \mathrm{CH}_{2}-7^{\prime}\right)$ was assignable to a methylene connecting the piperazine heterocycle to the aromatic ring. The presence of a 1-piperidinyl moiety was justified by three signals at $\delta 3.51-3.46\left(\mathrm{~m}, 4 \mathrm{H}, \mathrm{CH}_{2}-2\right.$ and $\left.\mathrm{CH}_{2}-6\right), 1.53$ (br. s, $4 \mathrm{H}, \mathrm{CH}_{2}-3$ and $\left.\mathrm{CH}_{2}-5\right)$ and 1.35 (br. s, $2 \mathrm{H}, \mathrm{CH}_{2}-4$ ). The ${ }^{1} \mathrm{H}$ NMR spectrum of this compound is shown in Figures S1 and S2.

The carbon skeleton of this molecule was also fully supported by its ${ }^{13} \mathrm{C}$ NMR spectrum, shown in the Figure S3. The ${ }^{13} \mathrm{C}$ NMR spectrum demonstrated overall fifteen carbon resonances due to some symmetrical duplets in the molecule. The 4-substituted benzenesulfonyl group was characterized by two quaternary and two duplet methine signals at $\delta 144.16\left(\mathrm{C}-4^{\prime}\right), 134.72\left(\mathrm{C}-1^{\prime}\right), 129.90\left(\mathrm{C}-2^{\prime}\right.$ and C-6') and 127.87 (C-3' and C-5'). The phenyl ring attached to the nitrogen atom of piperazine was obvious by four signals $\delta 151.43$ (C-1"'), 129.37 (C-3"' and 5"'), 119.29 (C-4"') and 115.85 (C-2"' and C-6"'). The pseudo-symmetrical piperazine heterocycle was corroborated by two signals at $\delta 53.05$ (C-3" and C-5") and 47.04 (C-2" and C-6"), while the connecting methylene was rationalized by a signal at $\delta$ 61.72 (C-7'). The remaining signals $\delta 48.67,48.63$ (C-2 and C-6), 25.14 (C-3 and C-5) and 23.32 (C-4) were attributed to a piperidinyl heterocycle in the molecule. Thus, on the basis of the above cumulative evidences, the structure of 5 was confirmed and it was named as 1-phenyl-4-[4-(1-piperidinylsulfonyl)benzyl]piperazine. The structures of other compounds were verified in a similar pattern. The ${ }^{1} \mathrm{H}$ NMR and ${ }^{13} \mathrm{C}$ NMR of all other compounds are shown in supplementary data (Figures S4-S9). 


\section{2. Biological Activities (in vitro)}

\section{2. 1. Enzyme Inhibition Activity}

The synthesized bi-heterocyclic sulfonamides, $\mathbf{5 ,} \mathbf{8}$, 11, 14, were screened against tyrosinase and their in vitro inhibitory activities are presented in Table 1 . These molecules exhibited outstanding potentials, which are evident from their lower $\mathrm{IC}_{50}(\mu \mathrm{M})$ values, relative to standard, kojic acid, having $\mathrm{IC}_{50}$ value of $16.8320 \pm 1.1600 \mu \mathrm{M}$. Although, the experimental activity is cumulative for the whole molecule, however, nevertheless, a partial structure-activity relationship (SAR) was established by analyzing the effect of varying heterocyclic parts on the inhibitory potential. It needs to be mentioned, that except this variation of heterocyclic moiety, all other parts were the same in these molecules. The general structural parts of the inspected compounds are labeled in Fig. 1.

The comparison of inhibitory potential of $5\left(\mathrm{IC}_{50}=\right.$ $0.0586 \pm 0.0033 \mu \mathrm{M})$ and $8\left(\mathrm{IC}_{50}=0.4078 \pm 0.0151 \mu \mathrm{M}\right)$, revealed that the presence of an additional oxygen atom within the heterocyclic ring (4-morpholinyl group) in $\mathbf{8}$ resulted in a decrease of activity as compared to 5 , in which a simple piperidinyl ring was present. The compound $\mathbf{5}$ was the most active compound in the series as well. It means, the presence of piperidinyl ring is a credible option for the promising activity of such compounds (Fig. 2).

In compound 11, a para-methyl group was present at the piperidinyl ring (4-methyl-1-piperidinyl), while in 14 two methyl groups were present at the meta-positions of this heterocyclic part (Fig. 3). When the inhibitory potential of these two molecules is compared, it was perceived that molecule 14 with two methyl groups in variable heterocyclic part behaved as a slightly better inhibitor. It means when the methyl groups were present in a pseudo-symmetrical manner at 3 and 5 positions (3,5-dimethyl-1-piperidinyl), the compound $\mathbf{1 4}$ made some better interactions with the enzyme relative to its mono-methylated analogue 11.

Table 1. Tyrosinase inhibitory and hemolytic activity of tri-heterocyclic compounds.

\begin{tabular}{ll}
\hline Compounds & $\begin{array}{l}\text { Tyrosinase activity } \\
\text { IC }_{50} \pm \mathrm{SEM}(\mu \mathrm{M})\end{array}$ \\
\hline $\mathbf{1 1}$ & $0.0586 \pm 0.0033$ \\
\hline $\mathbf{1 4}$ & $0.4078 \pm 0.0151$ \\
\hline
\end{tabular}

$\mathrm{SEM}=$ Standard error of the mean; values are expressed in mean \pm SEM.

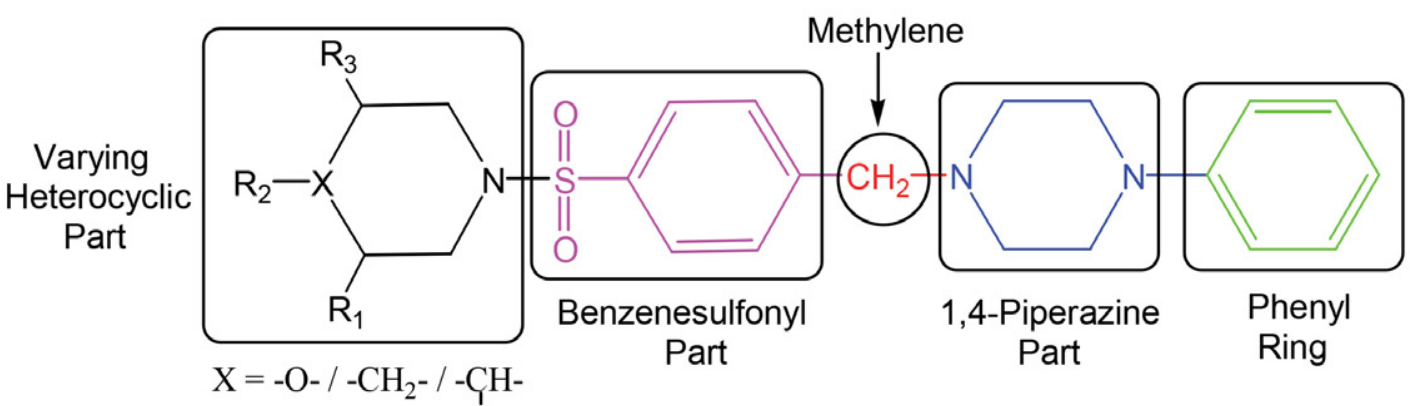

Figure 1. General structural parts of compounds 5, 8, 11, and 14 . 

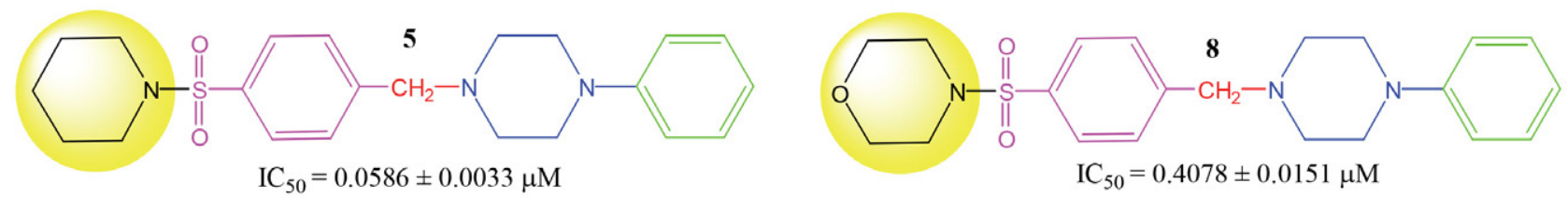

Figure 2. Structure-activity relationship of compounds $\mathbf{5}$ and $\mathbf{8}$.

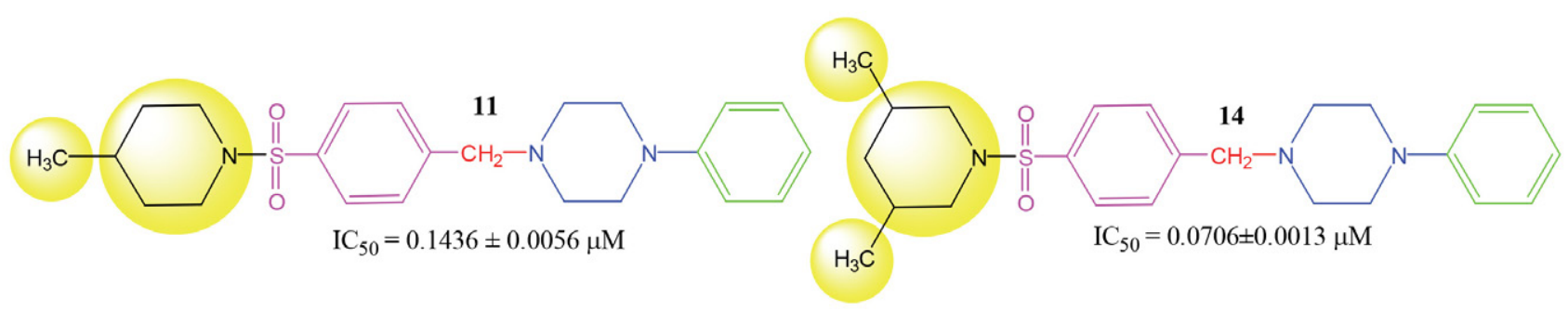

Figure 3. Structure-activity relationship of compounds 11 and 14.

Moreover, on a closer look, it was also elucidated that compounds 11 and 14 both have substituted piperidinyl ring and possessed slightly lesser inhibitory potentials as compared to $\mathbf{5}$ in which an un-substituted piperidinyl ring was present. From this, it was conceivable that the presence of any methyl group in this heterocyclic ring may render some steric repulsions and thus tending to retard the interactions of the compound with the enzyme, although to a minor extent. Hence, the presence of an un-substituted piperidinyl ring was the most suited option for the excellent activity of such molecules.

\section{2. 2. Kinetic Analysis}

To understand the inhibitory mechanism of these bi-heterocyclic sulfonamides on tyrosinase, kinetic study was performed. Based on our $\mathrm{IC}_{50}$ results, the most potent compound $\mathbf{5}$ was selected to determine the inhibition type and inhibition constant. The kinetic results (Table 2) of the enzyme by the Lineweaver-Burk plot of $1 / V$ versus $1 /[S]$ in the presence of different inhibitor concentrations gave a series of straight lines (Figure 4a). The result of Lineweaver-Burk plot of $\mathbf{5}$ showed that this compound intersected within the second quadrant. The analysis showed that $V_{\max }$ decreased in new increasing doses of inhibitors, on the other hand, $K_{\mathrm{m}}$ remains the same. This behavior indicated that 5 inhibited the tyrosinase non-competitively to form an enzyme-inhibitor complex. Secondary plot of slope against the concentrations of inhibitor showed enzyme-inhibitor dissociation constant $\left(K_{i}\right)$ (Figure $4 \mathrm{~b}$ ).

\section{2. 3. Mushroom Tyrosinase Structural Assessment}

Mushroom tyrosinase, a copper containing protein comprises 391 residues. The detail structure analysis of the target protein showed that it consists of $39 \%$ a-helices, $14 \% \beta$-sheets and $46 \%$ coils. The Ramachandran plots and values indicate that $95.90 \%$ of protein residues are present in the favored region and $100.0 \%$ residues lie in the allowed region. The Ramachandran graph values show good accuracy of phi $(\varphi)$ and psi $(\psi)$ angles among the coordinates of receptor and most of residues are plunged in the acceptable region. The overall protein structure and Ramachandran graph is shown in Figure 5 (A, B).

\section{2. 4. Computational Docking}

\section{2. 4. 1. Glide Energy Evaluation of Synthesized Compounds}

Molecular docking examination is the best approach to study the binding conformation of ligands within the

Table 2. Kinetic parameters of the mushroom tyrosinase for L-DOPA activity in the presence of various concentrations of compound 5 .

\begin{tabular}{lllll}
\hline $\begin{array}{l}\text { Concentration } \\
(\mu \mathbf{M})\end{array}$ & $\begin{array}{l}\boldsymbol{V}_{\max } \\
(\boldsymbol{\Delta} \mathbf{A} / \mathbf{M i n})\end{array}$ & $\begin{array}{l}\boldsymbol{K}_{\mathbf{m}} \\
(\mathbf{m M})\end{array}$ & Inhibition Type & $\begin{array}{l}\boldsymbol{K}_{\boldsymbol{i}} \\
(\boldsymbol{\mu M})\end{array}$ \\
\hline 0.00 & 0.000384 & 0.2222 & & \\
0.0586 & $7.105673 \times 10^{-5}$ & 0.2222 & & \\
0.1172 & $5.438583 \times 10^{-5}$ & 0.2222 & Non-Competitive & 0.09 \\
0.2344 & $3.968313 \times 10^{-5}$ & 0.2222 & & \\
\hline
\end{tabular}

Note: $\mathrm{V}_{\max }$ is the reaction velocity; $\mathrm{K}_{\mathrm{m}}$ is the Michaelis-Menten constant; $\mathrm{Ki}$ is the EI dissociation constant. 

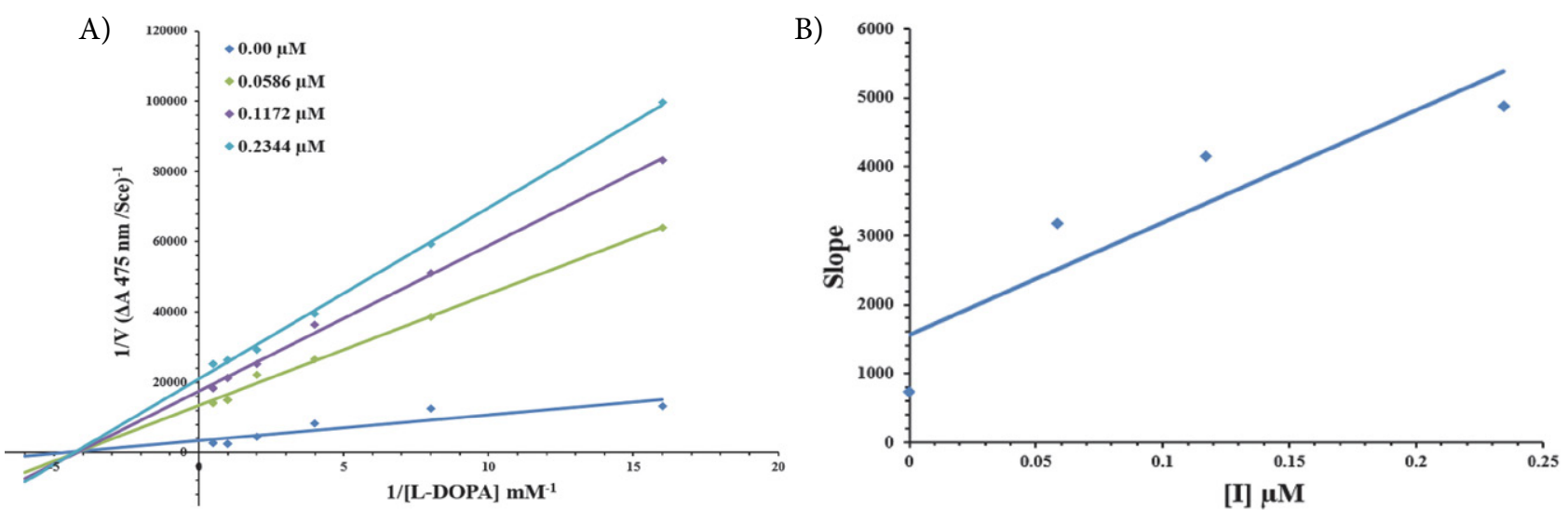

Figure 4. Lineweaver-Burk plots for inhibition of tyrosinase in the presence of compound 5. (a) Concentrations of 5 were $0.00,0.0586,0.1172$ and $0.2344 \mu \mathrm{M}$, respectively. Substrate L-DOPA concentrations were between 0.0625 and $2 \mathrm{mM}$, respectively. (b) The inset represents the plot of the slope versus inhibitor 5 concentrations to determine inhibition constant. The lines were drawn using linear least squares fit.
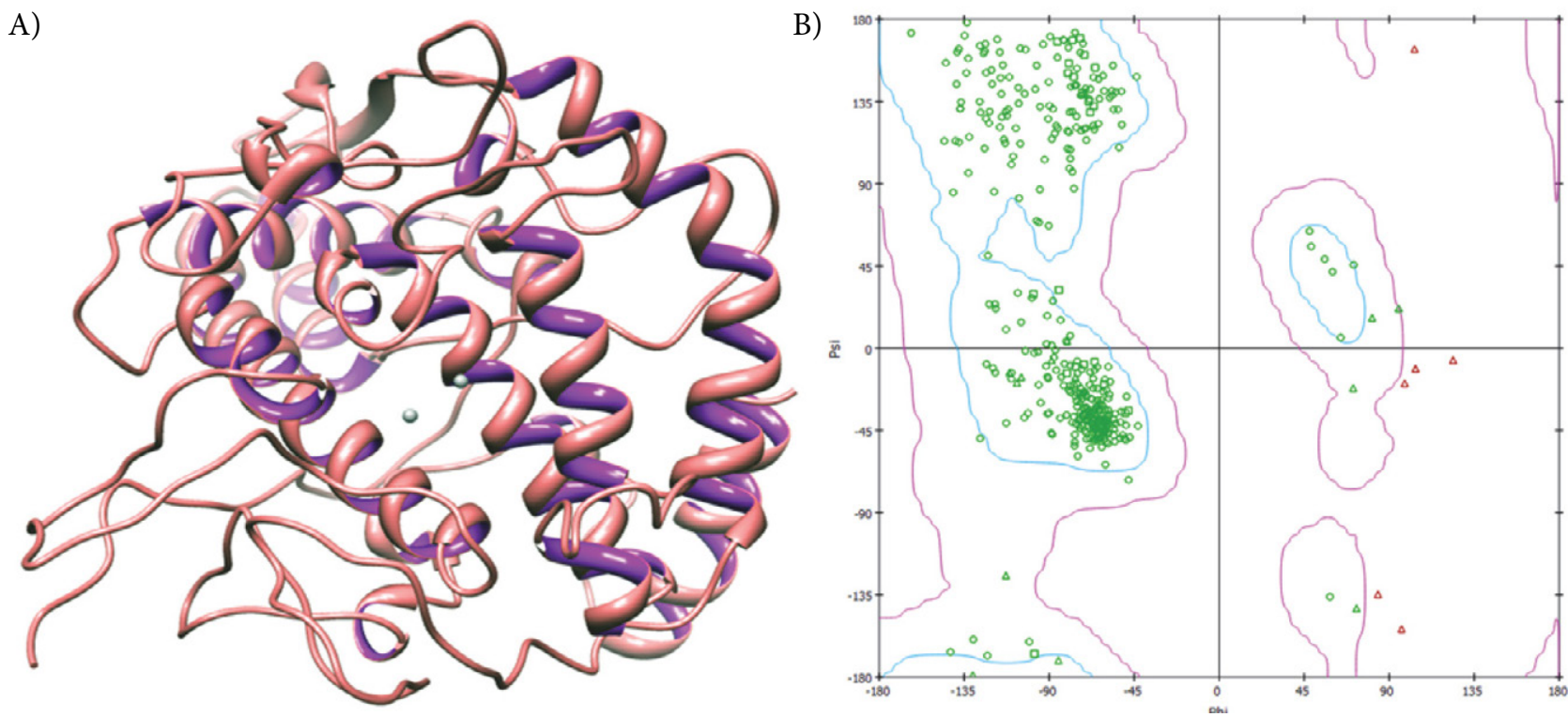

Figure 5. The overall protein structure (A) of tyrosinase and its Ramachandran graph (B).

active region of target proteins..$^{20,21}$ To predict the conformational positions of synthesized ligands, compounds $\mathbf{5}$, 8, 11 and 14 were docked against tyrosinase, separately. The generated docked complexes were examined on the basis of glide docking energy values $(\mathrm{kcal} / \mathrm{mol})$ and bonding interaction (hydrogen/hydrophobic) pattern. The docking results showed that all the ligands were bound within the active region of the target protein with different conformational poses (Figure 6A). The glide docking energy values fluctuated among all ligands $(5,8,11$ and 14) and exhibited well docking energy values $-4.50,-5.65$, -4.89 and $-5.81 \mathrm{kcal} / \mathrm{mol}$, respectively. The comparative results show that no big energy value differences were observed (Fig. 6B) as the basic skeleton of ligands was similar in all synthetic compounds with the variation of only one heterocyclic moiety.

\section{2. 4. 2. Ligand-Binding Analysis of Tyrosinase Docked Complexes}

It was envisaged that hydrogen bonds and $\pi-\pi$ interactions were observed in 8,11 and 14 docking complexes. In 5-tyrosinase docking no hydrogen bonds were observed, however its binding conformation was quite similar with other ligands docking complexes. In 8-tyrosinase docking complex three hydrogen bonds were observed at Glu322 and His85. The benzene ring form hydrogen bond with Glu322 having bond length $2.61 \AA$, whereas the oxygen atoms of benzenesulfonyl part were involved in hydrogen bonding against His85 having bond distances $2.67 \AA$ and $1.99 \AA$, respectively. In 11-tyrosinase docking couple of hydrogen bonds were observed between the benzene ring of ligand and tyrosinase residues His85 and Cys83 with bonds length $2.59 \AA$ and $2.46 \AA$, respectively. Moreover, the com- 

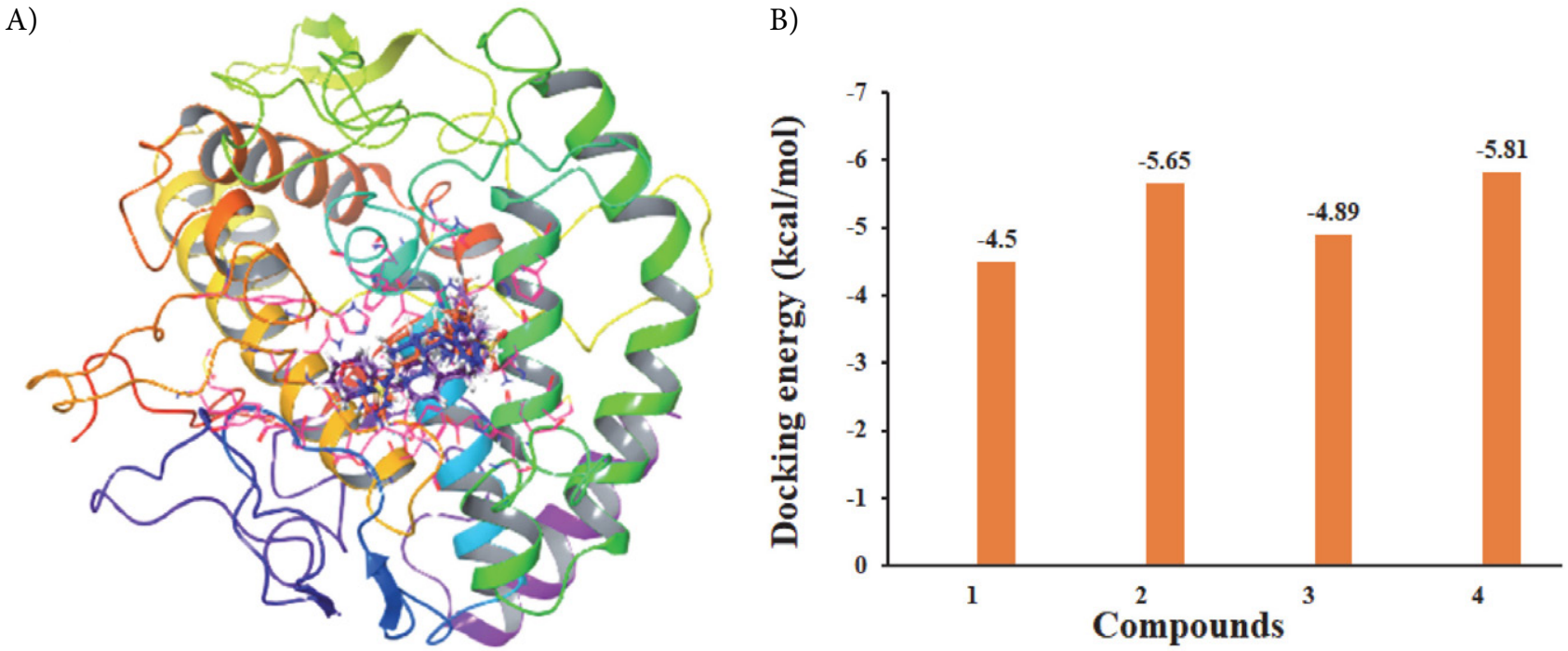

Figure 6. All the tyrosinase docking complexes (A) and their docking energy values (B).

pound 14 also showed two hydrogen bonds against His85 and Cys83 with bond distances $2.61 \AA$ and $2.27 \AA$, respec- tively. The 3D and 2D graphical representations of all docking complexes are shown in Figures 7, 8 and 9, respectively.

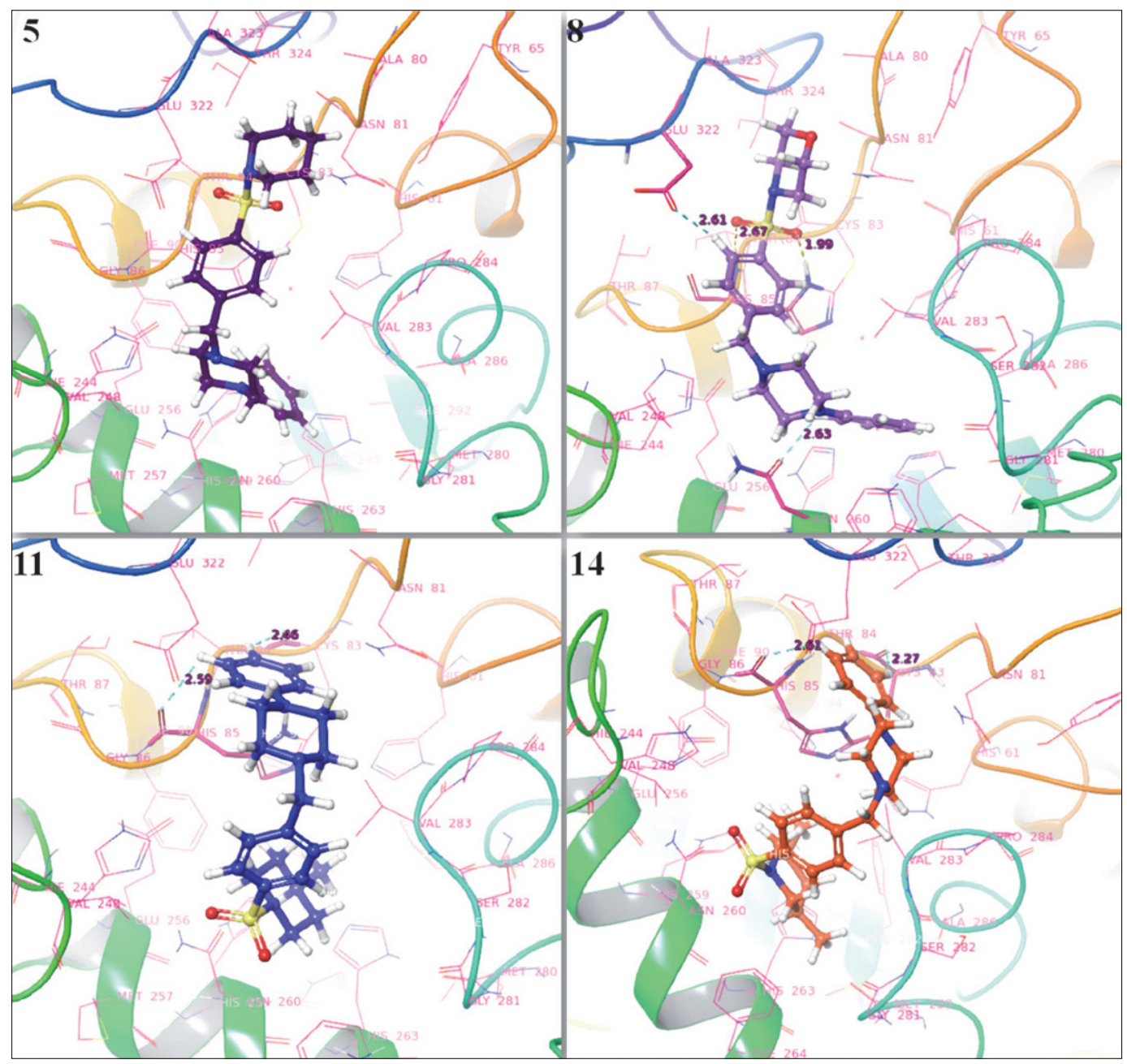

Figure 7. 3D binding interactions of 5, 8, 11 and $\mathbf{1 4}$ against tyrosinase protein.

Abbasi et al.: Synthesis of Bi-Heterocyclic Sulfonamides as Tyrosinase ... 

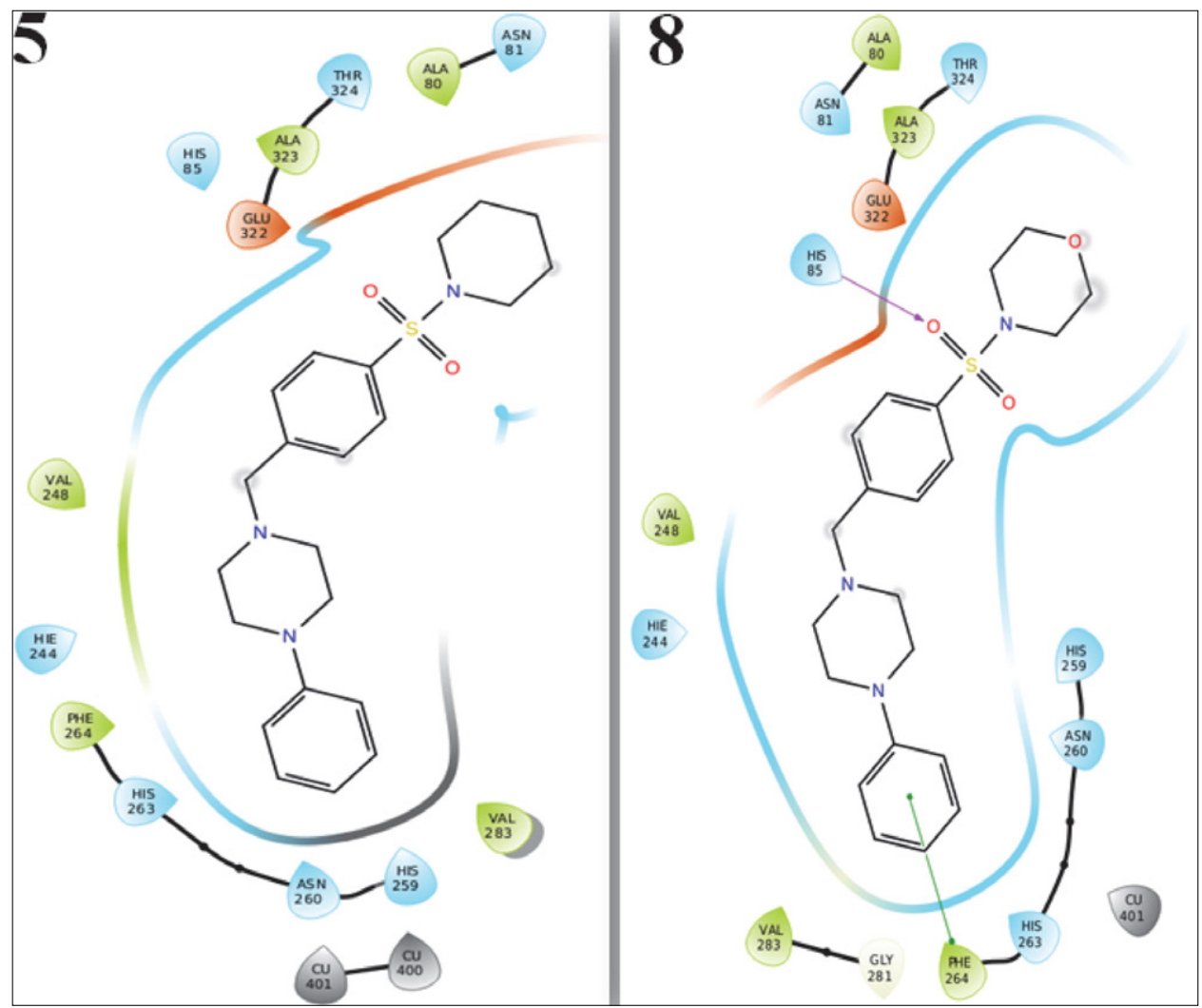

Figure 8. 2D binding interactions of $\mathbf{5}$ and $\mathbf{8}$ against tyrosinase protein.

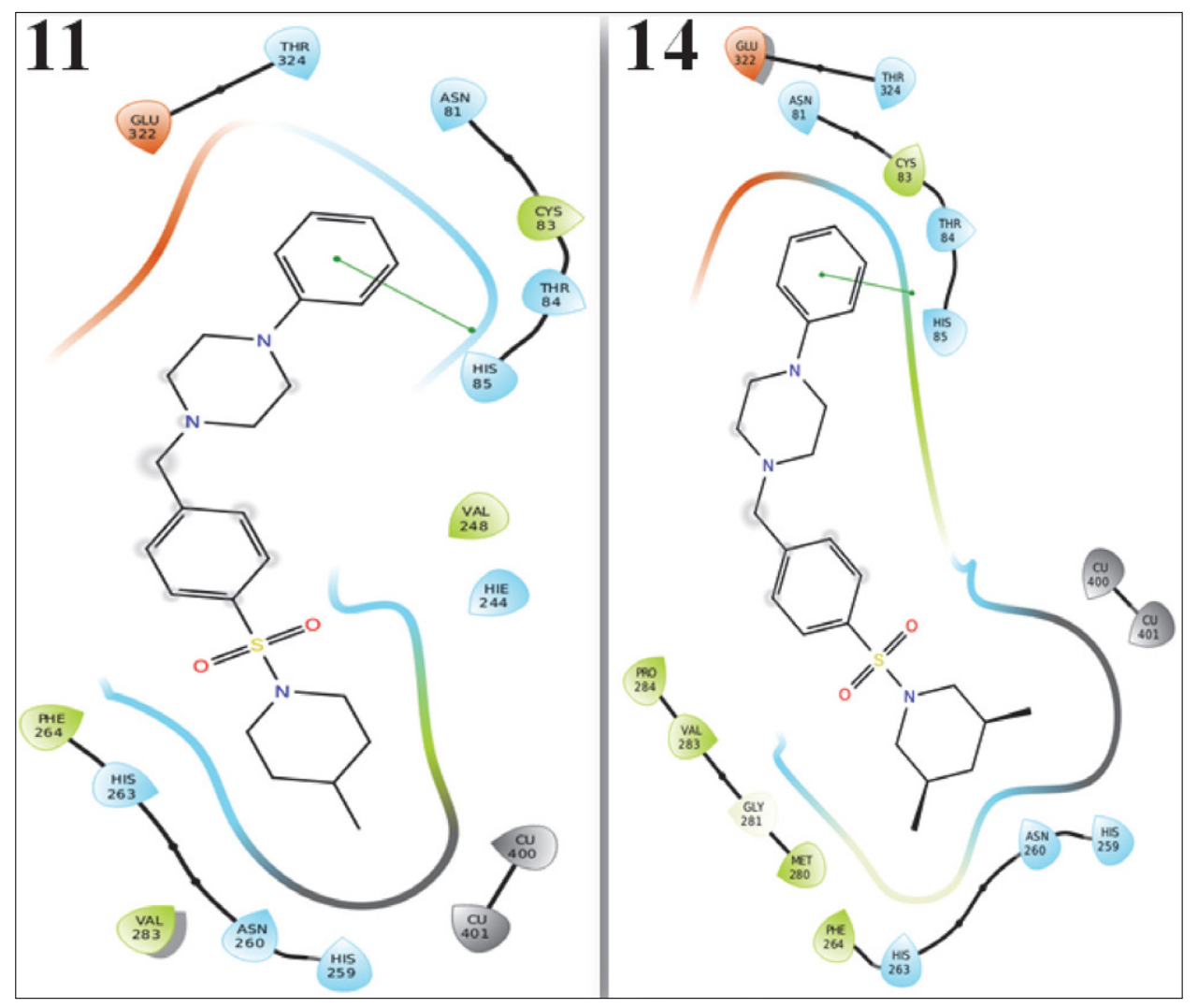

Figure 9. 2D binding interactions of $\mathbf{1 1}$ and $\mathbf{1 4}$ against tyrosinase protein. 
Moreover, computational results also explored the good binding profiles against target protein. All compounds $(5,8,11$, and 14$)$ exhibited good docking energy values and bound within active region of the target protein. His 85 was common in all docking results. The His85 is copper bonded residue which ensures that our ligands bind within the active region of the target protein. Literature data also ensured the importance of these residues in bonding with other tyrosinase inhibitors which strengthen our docking results. ${ }^{22,23}$ The comparative results showed that compound $\mathbf{5}$ might be considered as a superb template for the designing of new inhibitors against tyrosinase.

\section{Experimental}

\section{1. General}

All the chemicals, along with analytical grade solvents, were purchased from Sigma Aldrich, Alfa Aesar (Germany), or Merck through local suppliers. Pre-coated silica gel Al-plates were used for TLC with ethyl acetate and $n$-hexane as solvent system. Spots were detected by $\mathrm{UV}_{254}$. Gallenkamp apparatus was used to measure melting points in capillary tubes. Elemental analyses were performed on a Foss Heraeus CHN-O-Rapid instrument and were within $\pm 0.4 \%$ of the theoretical values. IR spectra ( $v$, $\mathrm{cm}^{-1}$ ) were recorded by $\mathrm{KBr}$ pellet method in the Jas-

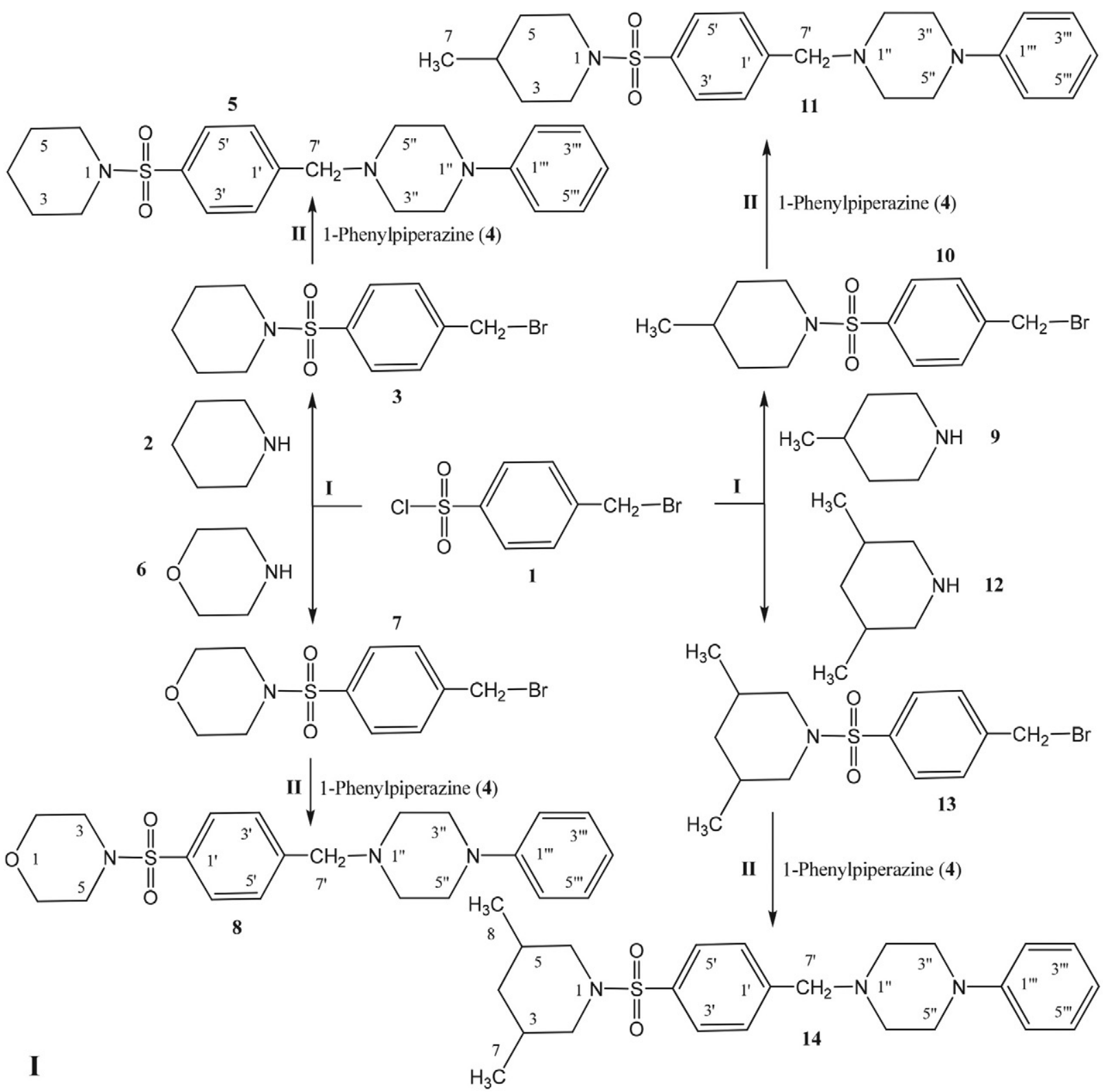

Scheme 1. Outline for the synthesis of 1-phenyl-4-[4-substituted-sulfonyl)benzyl]piperazines $(5,8,11,14)$. Reagents and conditions: (I) $10 \%$ $\mathrm{Na}_{2} \mathrm{CO}_{3}, \mathrm{pH}$ 9-10, stirring at room temperature for 3-4 h; (II) dimethylformamide (DMF), $\mathrm{LiH}$, refluxed for $0.5 \mathrm{~h}$, followed by addition of respective electrophile (one in each reaction) and then refluxing further for $4-5 \mathrm{~h}$. 
co-320-A spectrophotometer. ${ }^{1} \mathrm{H}$ NMR spectra $(\delta, \mathrm{ppm})$ were recorded at $600 \mathrm{MHz}\left({ }^{13} \mathrm{C} \mathrm{NMR}\right.$ spectra, at $\left.150 \mathrm{MHz}\right)$ in DMSO- $d_{6}$ using Bruker Advance III 600 As-cend spectrometer using $\mathrm{BBO}$ probe.

\section{2. Synthesis of 1-\{[4-(Bromomethyl)phenyl] sulfonyl\}un/substituted-piperidines (3, $10,13)$ and $1-\{[4-($ Bromomethyl)phenyl $]$ sulfonyl $\}$ morpholine (7)}

The synthesis of 1-\{[4-(bromomethyl)phenyl]sulfonyl $\}$ un/substituted-piperidines $(3,10,13)$ and $1-\{[4$-(bromomethyl)phenyl]sulfonyl $\}$ morpholine (7) was carried out by reaction of respective un/substituted-piperidines $(2,9,12)$ or morpholine (6) with 4-(bromomethyl)benzenesulfonyl chloride (1) in equimolar quantities $(0.001$ moles) and shaking manually in $10 \%$ aqueous $\mathrm{Na}_{2} \mathrm{CO}_{3}$ solution. Solid precipitates were formed after $2-3 \mathrm{~h}$, which were filtered and washed with cold distilled water to obtain the desired electrophiles $(3,7,10,13)$.

\section{3. General Procedure for the Synthesis of 1-Phenyl-4-[4-(substituted-sulfonyl) benzyl]piperazines $(5,8,11,14)$}

1-Phenylpiperazine $(0.2 \mathrm{~g}, 4)$ was added in DMF (5 $\mathrm{mL}$ ) contained in a $250 \mathrm{~mL}$ round bottom flask at room temperature, added one pinch of $\mathrm{LiH}$ and stirred for 30 min. Then the respective electrophile from 3, 7, 10, 13 (one in each reaction) was added in equimolar amount and stirred for 4-5 h. The completion of the reaction was monitored by TLC and after its completion, the reaction mixture was quenched with ice cold water $(100 \mathrm{~mL})$. Consequently, the respective derivatives $(5,8,11,14)$ were collected through filtration in purified form.

\section{1-Phenyl-4-[4-(1-piperidinylsulfonyl)benzyl]pipera- zine (5)}

White crystalline solid; yield: $72 \%$; m.p: $116-117^{\circ} \mathrm{C}$; mol. Formula: $\mathrm{C}_{22} \mathrm{H}_{29} \mathrm{~N}_{3} \mathrm{SO}_{2}$; mol. weight: $399 \mathrm{~g} / \mathrm{mol}$; IR $\left(\mathrm{KBr}, v, \mathrm{~cm}^{-1}\right) 2986$ (C-H, str. of aromatic ring), 2905 (- $\mathrm{CH}_{2}$ stretching), 1680 (aromatic $\mathrm{C}=\mathrm{C}$ stretching), 1382 $(\mathrm{S}=\mathrm{O}), 1115(\mathrm{C}-\mathrm{N}-\mathrm{C}) ;{ }^{1} \mathrm{H}$ NMR $\left(600 \mathrm{MHz}, \mathrm{DMSO}-d_{6}\right) \delta$ 7.70 (br. d, $J=7.6 \mathrm{~Hz}, 2 \mathrm{H}, \mathrm{H}-3$ ' and 5'), 7.60 (br. d, $J=7.6$ $\mathrm{Hz}, 2 \mathrm{H}, \mathrm{H}-2^{\prime}$ and 6'), 7.20 (br. t, $J=7.2 \mathrm{~Hz}, 2 \mathrm{H}, \mathrm{H}-3^{\prime \prime}$ ' and H-5"'), 6.92 (br. d, $J=7.7 \mathrm{~Hz}, 2 \mathrm{H}, \mathrm{H}-2$ "' and H-6"'), 6.77 (br. t, $J=6.9 \mathrm{~Hz}, 1 \mathrm{H}, \mathrm{H}-4^{\prime \prime}$ ), 3.63 (s, 2H, $\mathrm{CH}_{2}-7^{\prime}$ ), 3.51$3.46\left(\mathrm{~m}, 4 \mathrm{H}, \mathrm{CH}_{2}-2\right.$ and $\left.\mathrm{CH}_{2}-6\right), 3.14$ (br. s) and 2.87 (br. s) $\left(8 \mathrm{H}, \mathrm{CH}_{2}-2\right.$ ", $\mathrm{CH}_{2}-3$ ", $\mathrm{CH}_{2}-5$ " and $\mathrm{CH}_{2}-6$ "), 1.53 (br. s, $4 \mathrm{H}$, $\mathrm{CH}_{2}-3$ and $\left.\mathrm{CH}_{2}-5\right), 1.35$ (br. s, $\left.2 \mathrm{H}, \mathrm{CH}_{2}-4\right) ;{ }^{13} \mathrm{C} \mathrm{NMR}(150$ $\left.\mathrm{MHz}, \mathrm{DMSO}-d_{6}\right) \delta 151.43$ (C-1'”), 144.16 (C-4'), 134.72 (C-1'), 129.90 (C-2' and C-6'), 129.37 (C-3'” and C-5'”), 127.87 (C-3' and C-5'), 119.29 (C-4"'), 115.85 (C-2"' and C-6”'), 61.72 (C-7'), 53.05 (C-3" and C-5"), 48.67 and 48.63 (C-2 and C-6), 47.04 (C-2" and 6"), 25.14 (C-3 and C-5), 23.32 (C-4); Anal. Calcd. for $\mathrm{C}_{12} \mathrm{H}_{29} \mathrm{~N}_{3} \mathrm{SO}_{2}$ (399.20):
C, 66.13; H, 7.32; N, 10.52. Found: C, 66.17; H, 7.25; N, 10.50 .

4-(\{4-[(4-Phenyl-1-piperazinyl) methyl $]$ phenyl $\}$ sulfonyl)morpholine (8)

White crystalline solid; yield: $91 \%$; m.p: $176-177^{\circ} \mathrm{C}$; mol. Formula: $\mathrm{C}_{21} \mathrm{H}_{27} \mathrm{~N}_{3} \mathrm{SO}_{3}$; mol. weight: $401 \mathrm{~g} / \mathrm{mol}$; IR $\left(\mathrm{KBr}, v, \mathrm{~cm}^{-1}\right) 2981$ (C-H, str. of aromatic ring), 2901 (- $\mathrm{CH}_{2}$ stretching), 1678 (aromatic $\mathrm{C}=\mathrm{C}$ stretching), 1385 $(\mathrm{S}=\mathrm{O}), 1121(\mathrm{C}-\mathrm{N}-\mathrm{C}) ;{ }^{1} \mathrm{H}$ NMR $\left(600 \mathrm{MHz}, \mathrm{DMSO}-d_{6}\right) \delta$ 7.72 (br. d, $J=8.2 \mathrm{~Hz}, 2 \mathrm{H}, \mathrm{H}-2^{\prime}$ and $\mathrm{H}-6$ '), 7.64 (br. d, $J=$ $8.2 \mathrm{~Hz}, 2 \mathrm{H}, \mathrm{H}-3$ ' and $\mathrm{H}-5^{\prime}$ ), 7.21 (br. t, $J=7.6 \mathrm{~Hz}, 2 \mathrm{H}, \mathrm{H}-3$ '”' and $\mathrm{H}-5$ "'), 6.93 (br. d, $J=8.1 \mathrm{~Hz}, 2 \mathrm{H}, \mathrm{H}-2$ "' and $\mathrm{H}-6$ "'), 6.77 (br. t, $J=7.2 \mathrm{~Hz}, 1 \mathrm{H}, \mathrm{H}-4^{\prime \prime}$ '), 3.66 (s, 2H, $\mathrm{CH}_{2}-7^{\prime}$ ), 3.64 (dis. $\mathrm{t}, J=4.6 \mathrm{~Hz}, 4 \mathrm{H}, \mathrm{CH}_{2}-2$ and $\mathrm{CH}_{2}-6$ ), 3.15 (dis. $\mathrm{t}, J=$ $4.5 \mathrm{~Hz})$ and 2.86 (dis. $\mathrm{t}, \mathrm{J}=4.4 \mathrm{~Hz})\left(8 \mathrm{H}, \mathrm{CH}_{2}-2\right.$ ", $\mathrm{CH}_{2}-3$ ", $\mathrm{CH}_{2}-5$ " and $\mathrm{CH}_{2}-6$ "), 2.55 (dis. t, $J=4.7 \mathrm{~Hz}, 4 \mathrm{H}, \mathrm{CH}_{2}-3$ and $\left.\mathrm{CH}_{2}-5\right) ;{ }^{13} \mathrm{C}$ NMR $\left(150 \mathrm{MHz}, \mathrm{DMSO}-d_{6}\right) \delta 151.46(\mathrm{C}-$ 1'”), 144.72 (C-1'), 133.55 (C-4'), 129.99 (C-3' and C-5'), 129.36 (C-3"' and C-5'"), 128.16 (C-2' and C-6'), 119.27 (C-4"'), 115.85 (C-2"' and C-6"'), 65.76 (C-2 and C-6), 61.72 (C-7'), 53.09 (C-2" and C-6”), 48.70 (C-3 and C-5), 46.37 (C-3" and 5"); Anal. Calcd. for $\mathrm{C}_{21} \mathrm{H}_{27} \mathrm{~N}_{3} \mathrm{SO}_{3}$ (401.18): C, 62.82; H, 6.78; N, 10.47. Found: C, 62.78; H, $6.73 ; \mathrm{N}, 10.44$.

1-\{4-[(4-Methyl-1-piperidinyl)sulfonyl]benzyl $\}-4-$ phenylpiperazine (11)

White crystalline solid; yield: $76 \%$; m.p: $81-82{ }^{\circ} \mathrm{C}$; mol. Formula: $\mathrm{C}_{23} \mathrm{H}_{31} \mathrm{~N}_{3} \mathrm{SO}_{2}$; mol. weight: $413 \mathrm{~g} / \mathrm{mol}$; IR (KBr, v, cm $\left.{ }^{-1}\right) 2983(\mathrm{C}-\mathrm{H}$, str. of aromatic ring), 2900 (- $\mathrm{CH}_{2}$ stretching), 1676 (aromatic $\mathrm{C}=\mathrm{C}$ stretching), 1389 $(\mathrm{S}=\mathrm{O}), 1126(\mathrm{C}-\mathrm{N}-\mathrm{C}) ;{ }^{1} \mathrm{H}$ NMR $\left(600 \mathrm{MHz}, \mathrm{DMSO}-d_{6}\right) \delta$ 7.67 (dis. d, $J=7.6 \mathrm{~Hz}, 2 \mathrm{H}, \mathrm{H}-3^{\prime}$ and $\mathrm{H}-5^{\prime}$ ), 7.54 (dis. d, $J=$ $7.6 \mathrm{~Hz}, 2 \mathrm{H}, \mathrm{H}-2^{\prime}$ and H-6'), 7.20 (br. s, $2 \mathrm{H}, \mathrm{H}-3^{\prime \prime}$ ' and H-5"'), 6.92 (dis. d, $J=7.7 \mathrm{~Hz}, 2 \mathrm{H}, \mathrm{H}-2$ "' and $\mathrm{H}-6$ "'), 6.77 (br. s, $1 \mathrm{H}, \mathrm{H}-4$ "'), 3.63 (m, $1 \mathrm{H}, \mathrm{H}_{\mathrm{e}}-6$ ), 3.53 (s, $2 \mathrm{H}, \mathrm{CH}_{2}-7^{\prime}$ ), 3.38 (br. s, $1 \mathrm{H}, \mathrm{H}_{\mathrm{e}}-2$ ), 3.33 (br. s, $2 \mathrm{H}, \mathrm{H}_{\mathrm{a}}-2$ and $\mathrm{H}_{\mathrm{a}}-6$ ), 3.14 (br. s) and 2.74 (br. s) $\left(8 \mathrm{H}, \mathrm{CH}_{2}-2\right.$ ", $\mathrm{CH}_{2}-3$ "), $\mathrm{CH}_{2}-5$ " and $\mathrm{CH}_{2}-6$ "), $1.62\left(\mathrm{~m}, 2 \mathrm{H}, \mathrm{H}_{\mathrm{e}}-3\right.$ and $\left.\mathrm{H}_{\mathrm{e}}-5\right), 1.28(\mathrm{~m}, 1 \mathrm{H}, \mathrm{H}-4)$, $1.13\left(\mathrm{~m}, 2 \mathrm{H}, \mathrm{H}_{\mathrm{a}}-3\right.$ and $\left.\mathrm{H}_{\mathrm{a}}-5\right), 0.88$ (br. $\mathrm{d}, J=7.1 \mathrm{~Hz}, 3 \mathrm{H}$, $\left.\mathrm{CH}_{3}-7\right) ;{ }^{13} \mathrm{C}$ NMR (150 MHz, DMSO-d 6 ) $\delta 151.44$ (C-1"'), $144.94\left(\mathrm{C}-4^{\prime}\right), 134.73$ (C-1'), 129.63 (C-2' and C-6'), 129.34 (C-3"' and C-5"'), 127.83 (C-3' and C-5'), 119.25 (C-4"'), 115.84 (C-2"' and C-6"'), 61.74 (C-7'), 53.08 (C-2" and C-6"), 48.70 (C-3" and C-5"), 46.48 (C-2 and C-6), 33.27 (C-3 and C-5), 29.75 (C-4), 21.74 (C-7); Anal. Calcd. for $\mathrm{C}_{23} \mathrm{H}_{31} \mathrm{~N}_{3} \mathrm{SO}_{2}$ (413.21): C, 66.79; $\mathrm{H}, 7.56 ; \mathrm{N}, 10.16$. Found: C, 66.75; H, 7.49; N, 10.10 .

1-\{4-[(3,5-Dimethyl-1-piperidinyl)sulfonyl $]$ benzyl $\}-4$ phenylpiperazine (14)

White crystalline solid; yield: $70 \%$; m.p: $110-111^{\circ} \mathrm{C}$; mol. Formula: $\mathrm{C}_{24} \mathrm{H}_{33} \mathrm{~N}_{3} \mathrm{SO}_{2}$; mol. weight: $427 \mathrm{~g} / \mathrm{mol}$; IR $\left(\mathrm{KBr}, v, \mathrm{~cm}^{-1}\right) 2990$ (C-H, str. of aromatic ring), 2915 (- $\mathrm{CH}_{2}$ stretching), 1689 (aromatic $\mathrm{C}=\mathrm{C}$ stretching), 1388 
$(\mathrm{S}=\mathrm{O}), 1108(\mathrm{C}-\mathrm{N}-\mathrm{C}) ;{ }^{1} \mathrm{H}$ NMR $\left(600 \mathrm{MHz}, \mathrm{DMSO}-d_{6}\right) \delta$ 7.72 (br. d, $J=7.9 \mathrm{~Hz}, 2 \mathrm{H}, \mathrm{H}-3^{\prime}$ and $\mathrm{H}-5^{\prime}$ ), 7.60 (br. d, $J=$ $7.9 \mathrm{~Hz}, 2 \mathrm{H}, \mathrm{H}-2$ ' and H-6'), 7.20 (br. t, $J=7.7 \mathrm{~Hz}, 2 \mathrm{H}, \mathrm{H}-3^{\prime \prime}$ and $\left.\mathrm{H}-5^{\prime \prime}\right), 6.93$ (br. d, $J=8.1 \mathrm{~Hz}, 2 \mathrm{H}, \mathrm{H}-2$ "' and $\mathrm{H}-6$ "'), 6.77 (br. t, $J=7.1 \mathrm{~Hz}, 1 \mathrm{H}, \mathrm{H}-4$ '”), 3.64 (s, 2H, $\mathrm{CH}_{2}-7^{\prime}$ ), 3.62-3.60 (m, 4H, $\mathrm{CH}_{2}-2$ and $\mathrm{CH}_{2}-6$ ), 3.15 (br. s) and 2.54 (br. s) $\left(8 \mathrm{H}, \mathrm{CH}_{2}-2\right.$ ", $\mathrm{CH}_{2}-3$ ", $\mathrm{CH}_{2}-5$ " and $\mathrm{CH}_{2}-6$ "), $1.71-$ $1.63\left(\mathrm{~m}, 2 \mathrm{H}, \mathrm{CH}_{2}-3\right.$ and $\mathrm{CH}_{2}-5$ ), 0.92 (dis. d, $J=6.7 \mathrm{~Hz}$, $1 \mathrm{H}, \mathrm{H}_{\mathrm{e}}-4$ ), 0.82 (br. d, $J=6.0 \mathrm{~Hz}, 6 \mathrm{H}, \mathrm{CH}_{3}-7$ and $\mathrm{CH}_{3}-8$ ), $0.51\left(\mathrm{~m}, 1 \mathrm{H}, \mathrm{H}_{\mathrm{a}}-4\right) ;{ }^{13} \mathrm{C}$ NMR $\left(150 \mathrm{MHz}, \mathrm{DMSO}-d_{6}\right) \delta$ 151.45 (C-1'”), 144.20 (C-4'), 134.99 (C-1'), 129.90 (C-2' and C-6'), 129.35 (C-3'” and C-5"'), 127.81 (C-3' and C-5'), 119.26 (C-4"'), 115.85 (C-2"' and C-6"'), 61.73 (C-7'), 53.10 (C-2" and C-6"), 52.73 (C-2 and C-6), 48.65 (C-3" and C-5”), 41.09 (C-4), 30.94 (C-3 and C-5), 19.78 (C-7 and 8); Anal. Calcd. for $\mathrm{C}_{24} \mathrm{H}_{33} \mathrm{~N}_{3} \mathrm{SO}_{2}$ (427.23): C, 67.41; H, 7.78; N, 9.83. Found: C, 67.35; H, 7.69; N, 9.77.

\section{4. Biological Activity Assays (in vitro)}

\section{4. 1. Tyrosinase Inhibitory Activity}

The inhibition of mushroom tyrosinase was determined by a modification of the dopachrome method using L-DOPA as the substrate. ${ }^{24-27}$ In detail, $140 \mu \mathrm{L}$ of phosphate buffer ( $20 \mathrm{mM}, \mathrm{pH} 6.8), 20 \mu \mathrm{L}$ of mushroom tyrosinase $(30 \mathrm{U} / \mathrm{mL})$ and $20 \mu \mathrm{L}$ of the inhibitor solution were placed in the wells of a 96-well microplate. After pre-incubation for 10 minutes at room temperature, $20 \mu \mathrm{L}$ of L-DOPA (3,4-dihydroxyphenylalanine, Sigma Chemical, USA) $(0.85 \mathrm{mM})$ was added and the assay plate was further incubated at $25^{\circ} \mathrm{C}$ for 20 minutes. After incubation time, the absorbance was read at $475 \mathrm{~nm}$ and the inhibition percentage calculated in relation to the control. Phosphate buffer and kojic acid were tested under the same conditions as negative and positive control, respectively. The amount of inhibition by the test compounds was expressed as the percentage of concentration necessary to achieve $50 \%$ inhibition $\left(\mathrm{IC}_{50}\right)$. Each concentration was analyzed in three independent experiments. $\mathrm{IC}_{50}$ values were calculated by nonlinear regression using GraphPad Prism 5.0.

The \% inhibition of tyrosinase was calculated as following:

$$
\text { Inhibition }(\%)=\frac{\mathrm{B}-\mathrm{S}}{\mathrm{B}} \cdot 100
$$

Here, the B and S are the absorbances for the blank and samples.

\section{4. 2. Kinetics Assay}

On the basis of $\mathrm{IC}_{50}$ results, the most potent molecule, 5, was selected for kinetic analysis. A series of experiments were performed to determine the inhibition kinetics of 5 by following the already reported methods. ${ }^{23,28}$ The inhibitor concentrations for 5 were $0.00,0.0586,0.1172$ and $0.2344 \mu \mathrm{M}$. Substrate L-DOPA concentrations were between 0.0625 to $2 \mathrm{mM}$ in all kinetic studies. Pre-incubation and measurement time was the same as discussed in the mushroom tyrosinase inhibition assay protocol. Maximal initial velocity was determined from the initial linear portion of absorbance up to five minutes after addition of enzyme at a $30 \mathrm{~s}$ interval. The inhibition type of the enzyme was assayed by Lineweaver-Burk plots of the inverse of velocities $(1 / \mathrm{V})$ versus the inverse of substrate concentration $1 /[\mathrm{L}-\mathrm{DOPA}] \mathrm{mM}^{-1}$. The EI dissociation constant $K_{i}$ was determined by the secondary plot of $1 / V$ versus inhibitors concentrations.

\section{4. 3. Molecular Docking Methodology}

\section{4. 3. 1. Retrieval of Tyrosinase in Protein Preparation Wizard}

The mushroom tyrosinase structure was retrieved from Protein Data Bank (PDB) (www.rcsb.org) with PDBID $2 \mathrm{Y} \mathrm{X}^{29}$ in protein preparation wizard. The selected protein structure of tyrosinase was pre-processed and minimized using default parameters in Maestro interface.

\section{4. 3. 2. Grid Generation and Molecular Docking}

Prior to molecular docking, the optimized tyrosinase structure was prepared using the "Protein Preparation Wizard" workflow in Schrödinger Suite. Bond orders were assigned and hydrogen atoms were added to the protein. The structure was then minimized to reach the converged root mean square deviation (RMSD) of $0.30 \AA$ with the OPLS_2005 force field. The active site of the enzyme was defined from the co-crystallized ligands from Protein Data Bank and literature data. ${ }^{30}$ Furthermore, docking experiment was performed against all synthesized ligands $(5,8$, 11 and 14) sketched by 2D sketcher in Maestro and target protein by using Glide docking protocol. ${ }^{31}$ The predicted binding energies (docking scores) and conformational positions of ligands within active region of protein were also performed using Glide experiment. Throughout the docking simulations, both partial flexibility and full flexibility around the active site residues were performed by Glide/ SP/XP and induced fit docking (IFD) approaches. ${ }^{32,33}$

\section{Conclusion}

A structurally unique series of sulfonamides, hybrid with a piperazine, and heterocyclic secondary amines, was synthesized and recognized with very superb tyrosinase inhibition. It was postulated from the SAR studies that molecules particularly bearing un-substituted or symmetrically methylated piperidinyl moiety, generally inhibited the tyrosinase in an excellent manner. So, it was concluded that molecule 5 in particular, and all these bi-heterocyclic sulfonamides in general, can be utilized as leading medicinal scaffolds for the treatment of melanogenesis. 


\section{Acknowledgement}

The present study was supported by Basic Science Research Program through the National Research Foundation of Korea (NRF) funded by the Ministry of Education (2017R1D1A1B03034948).

\section{References}

1. V. K. Jain, B. Jain, U. K. Sharma, K. U. Saha, D. Saha, Int. J. Curr. Pharm. Res. 2011, 3, 66-70.

2. S. Bag, R. Tulsan, A. Sood, H. Cho, H. Redjeb, W. Zhou, H. LeVine III, B. Török, M. Török, Bioorg. Med. Chem. Lett. 2015, 25, 626-630. DOI:10.1016/j.bmcl.2014.12.006

3. M. A. Abbasi, S. Manzoor, Aziz-ur-Rehman, S. Z. Siddiqui, I. Ahmad, R. Malik, M. Ashraf, Qurat-ul-Ain, S. A. A. Shah, Pak. J. Chem. 2015, 5, 23-29.

DOI:10.15228/2015.v05.i01.p04

4. J. Winum, A. Scozzafava, J. Montero, C. T. Supuran, Med. Res. Rev. 2006, 26, 767-792. DOI:10.1002/med.20068

5. Antipsychotic piperazine and piperadine derivative, Expert Opinion on Therapeutic Patents 1994, 4, 281-292. DOI:10.1517/13543776.4.3.281

6. H. Marona, A. Gunia, K. Słoczyńska, A. Rapacz, B. Filipek, M. Cegła, W. Opoka, Acta Pol. Pharm. 2009, 66, 571-578.

7. M. Somashekhar, A. R. Mahesh, Am. J. Pharm. Res. 2013, 3, 640-645.

8. A. Mendoza, S. Pérez-Silanes, M. Quiliano, A. Pabón, S. Galiano, G. González, G. Garavito, M. Zimic, A. Vaisberg, I. Aldana, A. Monge, E. Deharo, Exp. Parasitol. 2011, 12, 97-103. DOI:10.1016/j.exppara.2011.02.025

9. G. C. L. Ee, C. M. Lim, M. Rahmani, K. Shaari, C. F. J. Bong, Molecules 2010, 15, 2398-2404.

DOI:10.3390/molecules 15042398

10. H. Sugimoto, Y. Limura, Y. Yamanishi, K. Yamatsu, Bioorg. Med. Chem. Lett. 1992, 2, 871-876.

DOI:10.1016/S0960-894X(00)80547-8

11. F. M. Oliveira, L. C. A. Barbosa, V. M. M. Valente, A. J. Demuner, C. R. A. Maltha, A. de J. Oliveros-Bastidas, J. Pharm. Res. 2012, 5, 5326-5333.

12. L. He, Bayer. Schering. Pharma. 1998, 6, 132-145.

13. S. A. Shaker, M. I. Marzouk, Molecules 2016, 21, 155-164. DOI:10.3390/molecules21020155

14. C. A. Ramsden, P. A. Riley, Bioorg. Med. Chem. 2014, 22, 2388-2395. DOI:10.1016/j.bmc.2014.02.048

15. Y. J. Zhu, L. Qiu, J. J. Zhou, H. Y. Guo, Y. H. Hu, Z. C. Li, Q. Wang, Q. X. Chen, B. Liu, J. Enz. Inhib. Med. Chem. 2010, 25, 798-803. DOI:10.3109/14756360903476398
16. M. Brenner, V. J. Hearing, Photochem. Photobiol. 2008, 84, 539-549. DOI:10.1111/j.1751-1097.2007.00226.x

17. Y. J. Kim, K. S. Kang, T. Yokozawa, Food Chem. Toxicol. 2008, 7, 2466-2471.

18. R. A. Copeland, Evaluation of Enzyme Inhibitors in Drug Discovery: A Guide for Medicinal Chemists and Pharmacologists, Published by John Wiley \& Sons, Inc., Hoboken, New Jersey, 2005, Vol. 46. ISBN 0-471-68696-4.

19. J. Konc, S. Lešnik, D. Janežič, J. Cheminform. 2015, 7, article number: 48, 1-8. DOI:10.1186/s13321-015-0096-0

20. M. Hassan, Q. Abbas, Z. Ashraf, A. A. Moustafa, S. Y. Seo, Comput. Biol. Chem. 2017, 68, 131-142. DOI:10.1016/j.compbiolchem.2017.02.012

21. M. Hassan, Z. Ashraf, Q. Abbas, H. Raza, S. Y. Seo, Interdiscip. Sci. 2018, 10, 68-80. DOI:10.1007/s12539-016-0171-x

22. A .R. S. Butt, M. A. Abbasi, Aziz-ur-Rehman, S. Z. Siddiqui, H. Raza, M. Hassan, S. A. A. Shah, M. Shahid, S.-Y. Seo, Bioorg. Chem. 2019, 86, 459-472.

DOI:10.1016/j.bioorg.2019.01.036

23. F. A. Larik, A. Saeed, P. A. Channar, U. Muqadar, Q. Abbas, M. Hassan, S. Y. Seo, M. Bolte, Eur. J. Med. Chem. 2017, 141, 273-281. DOI:10.1016/j.ejmech.2017.09.059

24. H. Raza, M. A. Abbasi, Aziz-ur-Rehman, S. Z. Siddiqui, M. Hassan, Q. Abbas, H. Hong, S. A. A. Shah, M. Shahid, S-Y Seo, Bioorg. Chem. 2020, 94, article number: 103445, 1-8. DOI:10.1016/j.bioorg.2019.103445

25. Q. Abbas, Z. Ashraf, M. Hassan, H. Nadeem, M. Latif, S. Afzal, S. Y. Seo, Drug Des. Devel. Ther. 2017, 11, 20-29. DOI:10.2147/DDDT.S137550

26. S. Aamer, A. P. Mahesar, P. A. Channar, Q. Abbas, F. A. Larik, M. Hassan, H. Raza, S. Y. Seo, Bioorg. Chem. 2017, 74, 187196. DOI:10.1016/j.bioorg.2017.08.002

27. Z. Ashraf, M. Rafiq, N. Humaira, H. Mubashir, A. Samina, M. Waseem, A. Khurram, L. Jalifah, PloS One 2017, 12, e0178069. DOI:10.1371/journal.pone.0178069

28. Z. Ashraf, M. Rafiq, S. Y. Seo, M. M. Babar, Bioorg. Med. Chem. 2015, 23, 5870-5880. DOI:10.1016/j.bmc.2015.06.068

29. W. T. Ismaya H. J. Rozeboom, A. Weijn, J. J. Mes, F. Fusetti, H. J. Wichers, B. W. Dijkstra, Biochemistry 2011, 50, 5477-5486. DOI:10.1021/bi200395t

30. M. Hassan, Q. Abbas, H. Raza, A. A. Moustafa, S. S. Seo, Mol. Biosyst. 2017, 13, 1534-1544. DOI:10.1039/C7MB00211D

31. R. A. Friesner, R. B. Murphy, M. P. Repasky, L. L. Frye, J. R. Greenwood, T. A. Halgren, P. C. Sanschagrin, D. T. Mainz, J. Med. Chem. 2006, 49, 6177-6196. DOI:10.1021/jm051256o

32. W. Sherman, T. Day, M. P. Jacobson, R. A. Friesner, R. Farid, J. Med. Chem. 2006, 49, 534-553. DOI:10.1021/jm050540c

33. W. Sherman, H. S. Beard, R. Farid, Chem. Bio. Drug Des. 2006, 67, 83-94. DOI:10.1111/j.1747-0285.2005.00327.x 


\section{Povzetek}

$S$ pomočjo dvostopenjskega protokola smo sintetizirali načrtovane bi-heterociklične sulfonamide; njihove strukture smo določili s spektroskopskimi tehnikami, vključno z IR, ${ }^{1} \mathrm{H}$ NMR in ${ }^{13} \mathrm{C}$ NMR ter s $\mathrm{CHN}$ analizo. In vitro inhibitorne učinke teh sulfonamidov smo določili na tirozinazi, mehanizem kinetike pa smo analizirali z Lineweaver-Burkovimi grafi. Vezavni model teh molekul je bil določen s pomočjo študij računskega sidranja. Sintetizirane bi-heterociklične molekule so se izkazale kot učinkoviti inhibitorji glede na standard 5-hidroksi-2-(hidroksimetil)-4H-piran-4-on (»kojic acid «); spojina 5 je nekompetitivno inhibirala tirozinazo tako, da je tvorila kompleks encim-inhibitor. Inhibicijsko konstanto $K_{i}(0.09$ $\mu \mathrm{M})$ za spojino 5 smo izračunali iz Dixonovih grafov. Računski rezultati so pokazali, da vse spojine izkazujejo ugoden vezavni profil za tirozinazo in da interagirajo $\mathrm{z}$ aminokislinskimi ostanki v jedru tarčnega proteina. 